Omni-Akuatika, 14 (3): 53-59, 2018
ISSN: 1858-3873 print / 2476-9347 online
Research Article
journal homepage: $h t t p: / /$ ojs.omniakuatika.net

\title{
The Effect of Fermented Organic Feed on The Performance of Oithona sp. in Semi-Mass Culture Condition
}

\author{
Suminto $^{1 *}$, Diana Chilmawati ${ }^{1}$, Dicky Harwanto ${ }^{1}$ \\ ${ }^{1}$ Department of Aquaculture, Faculty of Fisheries and Marine Science, Diponegoro University, \\ Semarang 50275, Indonesia
}

${ }^{*}$ Corresponding author: suminto57@gmail.com

Received 29 March 2018; Accepted 25 November 2018; Available online 30 November 2018

\begin{abstract}
This research was aimed to know the effect of different fermented organic feed on the growth performance of Oithona sp. in semi-mass culture condition. The Oithona sp. cultures were fed with mixed organic fermentation of pulp, bran and fish meal by using probiotic microbes and phytoplankton cells. There were 4 treatments and 4 replicates in this study. Treatment A was the Oithona sp. cultured with addition of Chaetoceros calcitrans cells $\left(2 \times 10^{6}\right.$ cells $\left.\cdot \mathrm{mL}^{-1}\right)$ without fermented organic feed $\left(0 \mathrm{~g} \cdot \mathrm{L}^{-1}\right.$ of medium culture). While $\mathrm{B}, \mathrm{C}$, and $\mathrm{D}$ with addition of $C$. calcitrans cells and $0.5,1.0$, and $1.5 \mathrm{~g} \cdot \mathrm{L}^{-1}$ of fermented organic feed, respectively. The results showed that the dosage of fermented organic feed had significantly different effect $(P<0.05)$ on the growth performance of Oithona sp. culture. The best growth performance of Oithona sp. shown at the addition of $0.5 \mathrm{~g} \cdot \mathrm{L}^{-1}$ of fermented organic feed, with total density of $7.09 \pm 0.11 \mathrm{ind} \cdot \mathrm{mL}^{-1}$, population growth rate of $0.116 \pm$ 0.002 ind $\cdot \mathrm{d}^{-1}$ and eggs production of $7.88 \pm 0.93 \mathrm{eggs} \cdot$ ind $^{-1}$ of adult.
\end{abstract}

Keywords: Fermented, feed, growth, Oithona sp., semi-mass

\section{Introduction}

Feeding habits have become a consideration having important effects on the growth and population density of Oithona sp., in addition to environmental variables (Drillet et al., 2011; Rajthilak et al., 2014). Oithona sp culture has not been optimal because the composition of feed in Oithona sp culture has not been well developed. Some researchers have examined the composition of the Chlorella marina Butcher microalgae diet (1952), Isochrysis galbana Parker (1949), and Dunaliella sp. with a ratio of 2: 2: 2 in the growth performance of Oithona sp. However, this composition results in the growth performance of Oithona sp. which is lower than cultivation with the composition of Chlorella vulgaris Beyerinck [Beijerinck] (1890) and Skeletonema costatum (Greville) Cleve (1873) with a ratio of 1: 1 (Payne and Rippingale, 2000; Kleppel, 1993) and also also other studies on different microalgae diets in the same dose in the growth of Oithona sp. (Santhanam and Perumal, 2012; Vasudevan et al., 2013). Recently, the influence of different diets from phytoplankton cells on copepod growth performance, Oithona sp. in semi-mass culture has been examined (Chilmawati and Suminto, 2015). There were four types of phytoplankton cells, C. calcitrans, C. vulgaris, Nannochloropsis oculata (Droop) and $I$. galbana cells which were added as live food diets to determine the growth performance of Oithona sp. C. calcitrans cell diets provide the best Oithona sp growth performance (Chilmawati and Suminto, 2015). Some researchers have had the experience of mass culture Oithona sp. for marine fish farming purposes, even though the effort has not been successful (Molejon and Alvarez-Lajonchere, 2003). Among them are studies on the growth of Chanos chanos (Raj et al., 2003), and on the growth and survival rate of Lates calcalifer Bloch (1790) (Santhanam and Perumal, 2014). Research on feeding habits, egg production rates, and the growth of Oithona sp. were also examined by Lampitt and Gamble (1982) and Vogt et al. (2013).

Based on its nutritional content, copepods have a high protein content $(69.24 \pm$ $0.00 \%$ ) compared to Artemia nauplii (59.21 \pm $0.087 \%$ ) and rotifer $(62.84 \pm 0.052 \%$ ) (Olivotto et al., 2010). Oithona sp. as live food compared with artemia and rotifer, or with other copepods 
on the growth of gouper larvae, Cromileptes altivelis Valenciennes (1828) has significantly increased to eicosapentaenoic acid (EPA) and docosahexaenoic acid (DHA) of $C$. altivelis (Aliah et al., 2010). Organic fermented feed can be used to increase the nutritional value of Oithona sp. along with phytoplankton cell diets. The fermentation process can increase the content of organic- $\mathrm{C}$ and organic-N complexes to be simpler formed by bacteria, where the goal is to reduce nourishing compounds, increase yield and nutritional value, increase digestion rate of Oithona sp. and also to increase the availability of vitamins such as vitamin B12, B6 and riboflavin (Felix and Brindo, 2008). Oithona sp. requires bacteria and reshuffle organic particles produced by bacteria as their food. Several studies have shown that bacterial biomass and detritus are superior food sources to increase population in the growth of harpacticoid copepods (Drillet et al., 2011; Lampitt and Gamble, 1982; Vogt et al., 2013). Phytoplankton feed mixtures, C. calcitrans cells and organic materials from pulp, bran and fish flour fermented using probiotic microbes can improve the culture of Oithona sp. However, this study is important to know the production of Oithona sp. cultured by using fermented organic feed which is a local natural food as an alternative substitution of live food organisms for the maintenance of shrimp larvae and finfish in Indonesian hatcheries. This study was intended to investigate the effects of some fermented organic feed on the growth performance of Oithona sp. in semi-mass culture.

\section{Material and Method}

Preparation of C. calcitrans culture.

Monoculture microalgae of $C$. calcitrans cells were taken from a living food laboratory Brackish Water Aquaculture Development Center (BWADRC), Jepara then cultured into 6 $\mathrm{L}$ transparent plastic bottles filled with $4 \mathrm{~L}$. sterilized sea water. The sterilization of sea water used was filtered with $10 \mu \mathrm{m}$ and the place was received in $100 \mathrm{~L}$ circular plastic drum with an additional $60 \mathrm{mg} \cdot \mathrm{L}^{-1}$ sodium hypochoride solution. This sea water was stored for about 10-30 minutes, and then added $80 \mathrm{mg}$ sodium thiosulfate solution $\cdot \mathrm{L}^{-1}$ with aeration for 24 hours for the dechlorination process. Before being used for cell culture of $C$. calcitrans, sea water was added to several chemical compounds carried out by Suminto and Hirayama (1997) and autoclaved for 15 minutes with a pressure of $1 \mathrm{~atm}$ and $121^{\circ} \mathrm{C}$. Cells of $C$. calcitrans were cultured in $4 \mathrm{~L}$ in a volume culture medium in indoor culture conditions with an initial density of $5 \times 104$ cells - $\mathrm{mL}^{-1}$. Those cultured $C$. calcitrans cells were weakened by aeration, light intensity ranged from 2,000 to 3,000 lux and temperatures from 26-28 ${ }^{\circ} \mathrm{C}$ with 24-hour lighting. C. calcitrans cells were cultured for 8 days and harvested on days 6 to 8 , which were the increasing cells into the stationary growth pattern of the peak population growth (Suminto and Hirayama, 1997). Before adding $C$. calcitrans cells to Oithona sp. culture, the results of $C$. calcitrans cell culture were centrifuged for 15 minutes by IEA Centra CL2 with $100 \mathrm{n} \mathrm{rad} \cdot \mathrm{s}^{-1}$.

\section{Fermented organic feed}

The fermented organic feed was made from a mixture of organic material from $35 \%$ pulp, 35\% bran and 30\% fish flour in powder form with an average diameter range of 50-100 $\mu \mathrm{m}$. Proximate analysis was carried out before and after the fermentation process to determine the nutritional content of all organic ingredients. The material used was a sterile plastic tube, which was filled with $10 \mathrm{~mL}$ of probiotic microbes containing Lactobacillus casei, Sacharomyces cereviceae, and Bacillus $\mathrm{sp}$. Then, it mixed with $200 \mathrm{~mL}$ of sterile sea water and $25 \mathrm{ml}$ of molasses for $1 \mathrm{~kg}$ of mixed organic matter. Furthermore, it was incubated for fermentation for 48 hours before feeding on the culture of Oithona sp.

\section{Culture of Oithona sp.}

Sterilized seawater with salinity of $30 \%$ was used as culture media of Oithona sp. The Oithona sp. cultures were prepared in 16 of $4 \mathrm{~L}$ transparent circular plastic bottles with each containing of $2 \mathrm{~L}$ seawater. The initial density of Oithona sp. was given $1 \mathrm{ind} \cdot \mathrm{mL}^{-1}$. All of plastic bottle treatments were cultured during 16 days and given aeration with environmental conditions of salinity and temperature ranged from 28 to $30 \%$ and 27 to $29^{\circ} \mathrm{C}$, respectively. The growth of $C$. calcitrans cells at the peak population that cultured during 6-8 days were calculated by a haemocytometer and harvested for fed into the cultures of Oithona sp. The Oithona sp. cultures were added by $2 \times 10^{6}$ cells $\cdot \mathrm{mL}^{-1}$ of $C$. calsitrans cells and each of those treatment dosages of fermented organic feed every day.

\section{Calculation and data analysis}

Spesific growth constanta ( $r)$ was calculated based on formula from Hagiwara et. al. (1993) 


$$
r=1 / T \ln N_{T} / N_{0}
$$

where $T$ is days needed to achieve maximum growth, $\mathrm{N}_{\mathrm{T}}$ is Oithona sp. density on day $\mathrm{T}$ and $\mathrm{N}_{0}$ is initial density of Oithona sp.

According to Yu and Hirayama (1986), Net Reproductive Rate is the number of eggs produced by the female parent on average during their lifetime. $R_{0}$ values are influenced by the daily fecundity and survival (Hirayama and Satuito, 1991)

$$
R_{0}=\sum l_{x} m_{x}
$$

where $I_{x}$ is survival rate at a certain age and $\mathrm{m}_{\mathrm{x}}$ is the birth rate at a certain age (the number of eggs produced by females of a certain age).

\section{Experiment design and statistical analysis}

The Completely Randomized Design (CRD) was applied using four treatments and three replications. Treatment A was the Oithona sp. cultured with added $C$. calcitrans cells of $2 \times$ $10^{6}$ cells $\cdot \mathrm{mL}^{-1}$ without addition of fermented organic feed $\left(0 \mathrm{~g} \cdot \mathrm{L}^{-1}\right)$. While treatments of $B$, $\mathrm{C}$, and $\mathrm{D}$ were the same added by $C$. calcitrans cells of $2 \times 10^{6}$ cells $\cdot \mathrm{mL}^{-1}$ with $0.5 \mathrm{~g} \cdot \mathrm{L}^{-1}, 1.0$ $\mathrm{g} \cdot \mathrm{L}^{-1}$, and $1.5 \mathrm{~g} \cdot \mathrm{L}^{-1}$ fermented organic feed, respectively. Data was analized by analysis of variance (ANOVA) to determine the effect of different dosage of the fermented organic feed on growth performance of Oithona sp. cultured in semi-mass condition. The LSD test $(\alpha=0.05)$ by using SPSS 16 was conducted when the treatment had effect significantly.

\section{Result and Discussion}

There was different quality in fermented organic food before and after being fermented using organic materials. Proximate analysis of protein, fat and ash and also BETN showed increase after fermentation process of before and after fermented organic material (Table 1). There were small different in protein content before and after fermentation process but the content of fat was much higher $(10.45 \%)$ in fermented organic material compared to that of non-fermented organic materials (3.33\%) used as feed. The difference in high fat content in fermented organic feed has a different effect on the growth performance of Oithona sp. in semi-mass culture.

Table 1 Proximate of organic materials before and after fermented

\begin{tabular}{ccc}
\hline $\begin{array}{c}\text { Levels in } \\
100 \% \text { dry matter }\end{array}$ & $\begin{array}{c}\text { Non-fermented } \\
\text { organic material }\end{array}$ & $\begin{array}{c}\text { Fermented } \\
\text { organic material }\end{array}$ \\
\hline Protein $(\%)$ & 26.397 & 26.678 \\
Crude fiber (\%) & 29.366 & 27.160 \\
Fat (\%) & 3.331 & 10.447 \\
Ash (\%) & 19.871 & 27.770 \\
BETN (\%) & 13.654 & 14.702 \\
\hline
\end{tabular}

Growth performance of Oithona sp. The mean of density was the total number of Nauplies, Copepodits and adult copepods, including the adult female containing with eggs sacs (Fig. 1). 


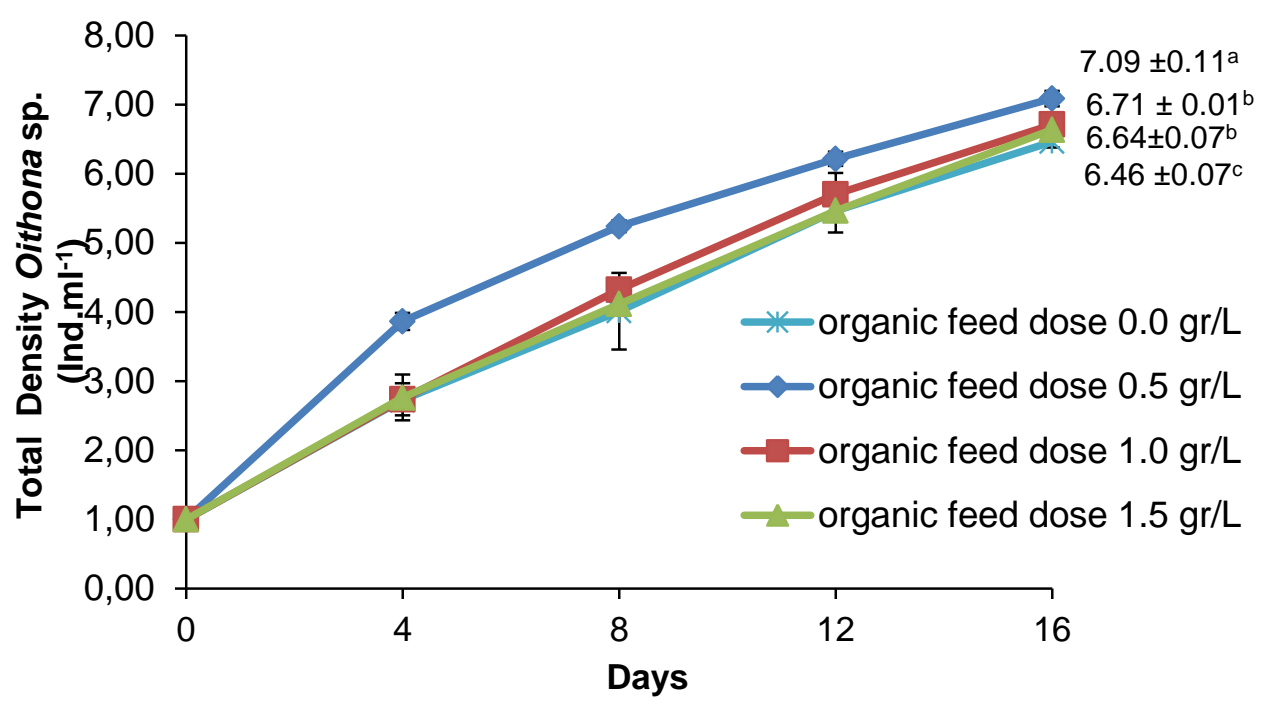

Figure 1: The density of Oithona sp. during $16 \mathrm{~d}$ culture period. Values are mean with standard deviation of four replications. Values not sharing the same letter are different significantly from one another $(P<0.05)$ by Least Significant Difference Test

The density of Oithona sp. cultured with addition of $0.5 \mathrm{~g} \cdot \mathrm{L}^{-1}$ fermented organic feed was $7.09 \pm 0.11$ ind $\cdot \mathrm{mL}^{-1}$, it was higher than those in treatments with addition of $0 \mathrm{~g} \cdot \mathrm{L}^{-1}$, $1.0 \mathrm{~g} \cdot \mathrm{L}^{-1}$, and $1.5 \mathrm{~g} \cdot \mathrm{L}^{-1}$ fermented organic feed (Figure 1). There showed that the feeding of $0.5 \mathrm{~g} \cdot \mathrm{L}^{-1}$ fermented organic feed were produced the best density of Oithona sp., where was also different significantly $(P<0.05)$ to that on other treatments (Fig. 1). The population growth rate of Oithona sp. with added the fermented organic feed of $1 \mathrm{~g} \cdot \mathrm{L}^{-1}$ and $1.5 \mathrm{~g} \cdot \mathrm{L}^{-1}$ were not different significantly $(P>0.05)$, but that of those were significant different $(P<0.05)$ to that of Oithona sp. growth rate in the treatment without addition of fermented organic feed (Figure 2).

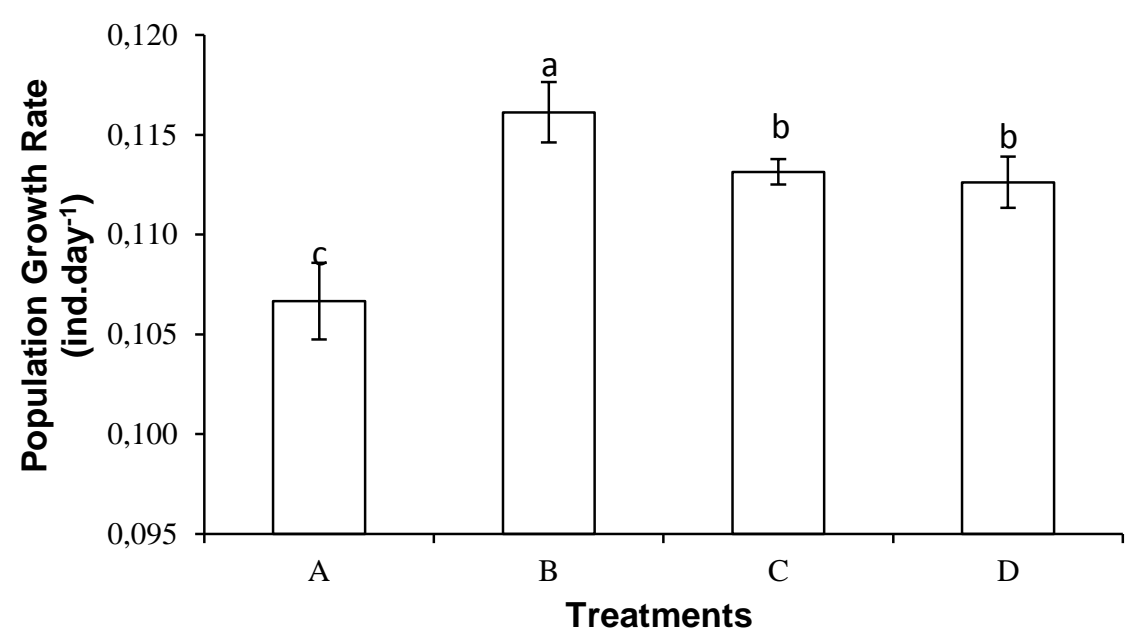

Figure 2: Population growth rate of Oithona sp. during 16 days culture period. Values are mean with standard deviation of four replications. Values not sharing the same letter are different significantly from one another $(P<0.05)$ by Least Significant Difference Test

C. calcitrans and $0.5 \mathrm{~g} \cdot \mathrm{L}^{-1}$ fermented organic feed were produced the best performance of Oithona sp. growth rate (Figure 2 ), and that treatment was also significant different $(P<0.05)$. In the Figure 2 showed the population growth rate of Oithona sp. between $1 \mathrm{~g} \cdot \mathrm{L}^{-1}$ and $1.5 \mathrm{~g} \cdot \mathrm{L}^{-1}$ were not significant different $(P>0.05)$. 
The treatment without fermented organic feed showed the small result of Oithona sp. growth performance and it was significant different $(P<$ $0.05)$. The highest egg production rate on the last day of culture was also showed by treatment using $0.5 \mathrm{~g} \cdot \mathrm{L}^{-1}$ fermented organic feed (Fig. 3).

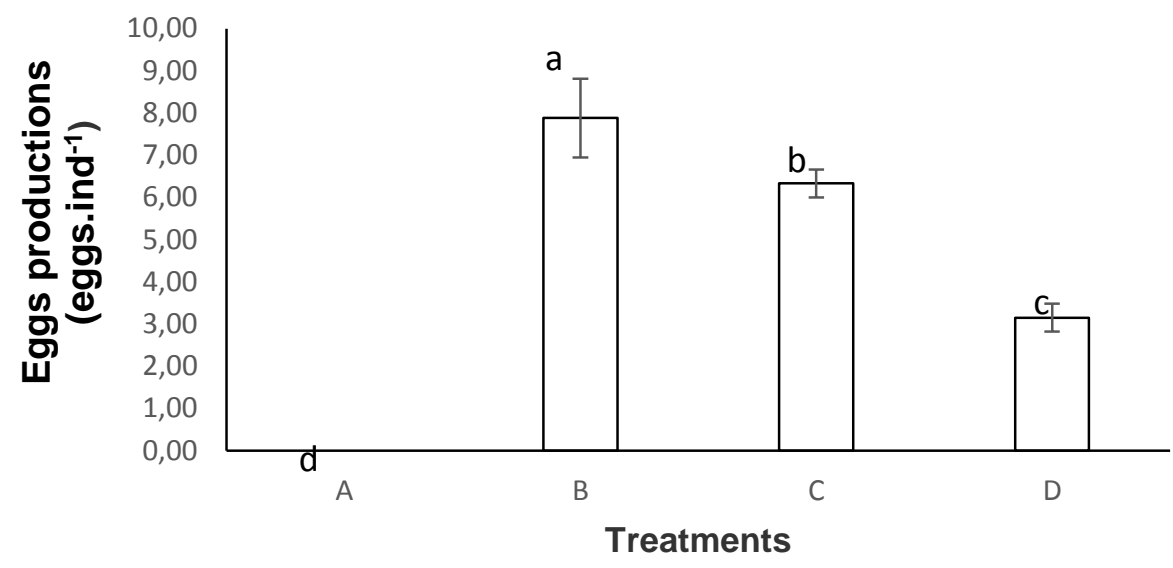

Fig.3: Egg production rate of Oithona sp. during $16 \mathrm{~d}$ culture period. Values are mean with standard deviation of four replications. Values not sharing the same letter are different significantly from one another $(P<0.05)$ by Least Significant Difference Test

\section{Discussion}

Fermentation process increase organic matters nutritional content and digestibility. The result of crude fiber on fermented organic feed was decreased from 29.37 to $47.16 \%$. It showed that fermentation can fixed the digestibility of organic matters. Oithona sp. could easily utilize the nutrition content in fermented organic feed. There were protein, fat, ash and BETN. Each of nutrition has their own function for Oithona sp. Protein is a major fraction compared lipids and carbohydrates, which shows the usefulness as a backup energy and metabolize-able substrate (Rajthilak et al., 2014; Vidhya et al., 2014). Carbohydrate is energy source that not too high, but a derivative of glucose also plays a necessary role in molting. In addition, the lipid is a major energy source and as a backup energy supply essential fatty acids needed for maintenance and sturdiness cellular membranes and also provides forming steroids and hormones molting (Shantanam and Perumal, 2012). This experiment was using probiotic bacteria for fermentation process. Microorganism might improve the host physiology by contributing to the host nutrition supply of vitamins (vitamin C, vitamin B12, retinol and others), protein, amino acids and delivering enzymes which stay active in the host intestine (Rajthilak et al., 2014)
The different dosage of fermented organic feed for culturing Oithona sp. showed the significant effect $(P<0.05)$ on growth performance. The Oithona sp. growth cultured without fermented organic feed was significant different $(P<0.05)$ on total density and population growth rate. On the other hand, the culture with added by combination feed of $0.5 \mathrm{~g}$ $\cdot \mathrm{L}^{-1}$ fermented organic feed had the best growth performance of Oithona sp. than other treatments. Treatment A performed the worst, where no female with egg on the last day of culture. That condition showed that there was a great impact on adding fermented organic feed for Oithona sp. culture media. Diet is one of the important factors for the culture of marine copepods (Vidhya et al., 2014). Rajthilak et al. (2014), have cultured copepods, Nitokra affinis Gurney (1927) by applying monodiet only, but the level of production would be higher if a binary or mixed diet was applied.

The best result of Oithona sp. growth performance was showed by the addition of 0.5 $\mathrm{g} \cdot \mathrm{L}^{-1}$ fermented organic feed in the culture medium, with the result of increasing growth. Media culture with the addition of $1 \mathrm{~g} \cdot \mathrm{L}^{-1}$ and $1.5 \mathrm{~g} \cdot \mathrm{L}^{-1}$ fermented organic feed were not significant different and both were not good on growth performance. Addition of high quality fermented organic feed will increase the growth performance and egg production. (Drillet et al.,2011). 


\section{Conclusions}

The administration of different doses of fermented organic feed showed a significant difference $(P<0.05)$ on the growth of Oithona $\mathrm{sp}$. Oithona $\mathrm{sp}$ best growth performance showed by adding $0.5 \mathrm{~g} \cdot \mathrm{L}^{-1}$ fermented organic feed on Oithona sp. The results were $6.413 \pm$ 155 ind $\cdot \mathrm{mL}^{-1}$ of total density, $0.091 \pm 0.002$ ind $\cdot$ day $^{-1}$ of population growth rate and $7.88 \pm$ 9.28 eggs $\cdot$ ind $^{-1}$ from egg production. The Oithona sp has been fed not only from phytoplankton cells, especially $C$. calcitrans and Isochrysis galbana cells, but also by using some fermented organic ingredients such as $35 \%$ slurry mixture, $35 \%$ bran and $30 \%$ fish meal in powder form with a size range average diameter of 50 to $100 \mu \mathrm{m}$.

\section{Acknowledgements}

This work was funded by the Indonesian Ministry of Technology, Research, and Higher Education, especially for Directorate General of Research and Public Service through a research programed in 2015. We would like to thank Mrs. Vika Ratna Noviyanti for her help in laboratory work.

\section{References}

Aliah, R. S., Kusmiyati., Yaniharto, D. 2010. Pemanfaatan copepoda Oithona sp. sebagai pakan hidup larva ikan kerapu. [Application of copepoda Oithona sp. as live feed for grouper larvae]. Jurnal Sains dan Teknologi Indonesia. 12:45-52. [in Bahasa Indonesia].

Chilmawati, D., Suminto. 2015. The effect of different diet of phytoplankton cells on growth performance of copepod, Oithona sp. in Semi-Mass Culture. Paper presented in the $2^{\text {nd }}$ International Symposium of Aquatic Product Processing and Health. Semarang, Indonesia.

Drillet, G., Frouël, S., Sichlau, M. H., Jepsen, P. M., Højgaard, J. K., Joarder, A. K., Hansen, B. W. 2011. Status and recommendations on marine copepod cultivation for use as live feed. Aquaculture. 315, 155-166.

Felix, N., Brindo, R. A. 2008. Fermented feed ingredients as fish meal replacer in aquafeed production. Aquaculture Asia Magazine, 33-34.
Hirayama, K., Satuito, C. G., 1991. The nutritional improvement of baker's yeast for the growth of the rotifer, Branchionus plicatilis. In W. Fulks, and K. L. Main (Eds.). Rotifer and microalgae culture systems. Hawaii: The Oceanic Institute.

Kleppel, G. 1993. On the diets of calanoid copepods. Marine Ecology Progress Series, 99, 183-183.

Lampitt, R. S., Gamble, J.C. 1982. Diet and Respiration of the small planktonic marine copepod Oithona nana. Marine Biology, 66(2):185-190.

Molejon, O. G. H., Alvarez-Lajonchere, L., 2003. Culture experiments with Oithona oculata Farran, 1913 (Copepoda: Cyclopoida), and it's advantages as food for marine fish larvae. Aquaculture, 219, 471-483.

Olivotto, I., Tokle, N. E., Nozzi, V., Cossignani, L., Carnevali, O. 2010. Preserved copepods as a new technology for the marine ornamental fish aquaculture: a feeding study. Aquaculture, 308, 124131.

Payne, M. F., Rippingale, R. J., 2000. Evaluation of diets for culture of the calanoid copepod Gladioferens imparipes. Aquaculture, 187, 85-96.

Raj, V. M.., Arasu, A. R. T., Kailasam, M., Subburaj, R., Thiagarajan, G. and Anuradha, 2003. Studies on the relative preference of rotlfer (Brachionus plicatilis), copepod (Oithona brevicornis) and Artemia Nauplii for milkfish (Chanos chanos) fry rearing. Proceedings of 3rd Interaction Workshop. Hisar, India. 1718 December 2003, pp 170-172 .

Rajthilak, C,. Santhanam, P., Anusuya, A., Pazhanimuthu, A., Ramkumar, R., Jeyaraj, N., Perumal, P. 2014. Laboratory culture and population growth of brackish water harpacticoid copepod, Nitokra affinis (Gurney, 1927) under different temperatures, salinities and diets. World Journal of Fish and Marine Sciences, 6 (1), 72-81.

Santhanam, P., Perumal, P. 2012 Effect of temperature, salinity and algal food concentration on population density, growth and survival of marine copepod Oithona rigida Giesbrecht. Indian Journal of Geo-Marine Sciences, 41(4):369-376.

Santhanam, P., Perumal, P., 2014 Evaluation of the marine copepod Oithona rigida 
Giesbrecht as live feed for larviculture of Asian seabass Lates calcarifer Bloch with special reference to nutritional value. Indian Journal of Fisheries, 59(2):127-134.

Suminto., Hirayama, K. 1997. Application of a growth-promoting bacteria for stable mass culture of three marine microalgae. Hydrobiologia, 358, 223-230.

Vasudevan, S., Arulmoorthy, M. P., Gnanamoorthy, P., Prabu, V. A. 2013. Intensive cultivation of the calanoid copepod Oithona rigida for mariculture purpose. International Journal of Pharmacy and Biological Sciences, 3:317-323.

Vidhya, K., Uthayakumar, V., Muthukumar, S., Munirasu, S., Ramasubramanian, V. 2014. The effects of mixed algal diets on population growth, egg productivity and nutritional in cyclopoid copepods (Thermocyclops hyalinus and Mesocyclops aspericornis). The Journal of Basic and Applied Zoology, 67(2):5865.

Vogt, R. A., Ignoffo, T. R., Sullivan, L. J., Herndon, J., Stillman, J. H., Kimmerer, W. J. 2013. Feeding capabilities and limitations in the nauplii of two pelagic estuarine copepods, Pseudodiaptomus marinus and Oithona davisae. Limnology and Oceanography, 58(6):2145-2157.

Yu, J. P., Hirayama, K. 1986. The effect of unionized ammonia on the population growth of the rotifer in mass culture. Bulletin of the Japanese Society for the Scientific Fisheries, 52(9):1509-1513. 